\title{
Research on Exploration and Practice of Blended Teaching Mode Reform in Ideological and Political Course Based on Moso Teach
}

\author{
Ai Jian \\ Xi'an Peihua University, Xi'an 710125, China
}

Keywords: Moso Teach; blended teaching mode; reform

\begin{abstract}
This paper analyzes the connotation, characteristics and significance of blended teaching and Moso Teach, and verifies the feasibility and purpose of blended teaching based on Moso Teach. Taking the courses of Introduction to Mao Zedong Thought and the theoretical system of socialism with Chinese characteristics and Outline of Modern Chinese History as an example, this paper discusses specific implementation process, results and experience of blended teaching based on Moso Teach.
\end{abstract}

\section{Introduction to Platform and Related Concepts}

\subsection{The connotation, characteristics and significance of blended teaching mode}

With the wide application of information big data, Internet and cloud computing in various fields in the $21^{\text {st }}$ century, it can be seen that students failing to preview, playing the phone in class and playing the game after class have become the common problem in colleges and universities under the impact of informationization. Therefore, to guide students to correctly make use of information technology platform to serve the innovation of education and teaching, build ideological and political course with equal communication, democratic discussion and interaction, and encourage students to learn, practice, think and speak out independently, teachers are required to choose the teaching mode and APP platform suitable for the implementation of teaching reform, and integrate effectively online teaching and offline teaching.

According to the requirement of education and teaching reform, blended teaching mode appear, which is the combination of online and offline teaching to make up for drawbacks of online learning. It is the superiority combination of online teaching and offline teaching under the background of informationization, and advantageous complement of traditional teaching method and network teaching. The appropriate application of blended teaching mode can not only give full play the guiding role of teachers in the entire teaching, also mobilize students' initiative, creativity and active participation by the aid of informationization. [1] At present, blended teaching mode has become the main teaching mode for teachers to conduct teaching reform and innovation under the background of informationization.

\subsection{The connotation, characteristics and significance of Moso Teach}

Based on practice and exploration of blended teaching mode in teaching in recent years, in its implementation, most teachers in colleges and universities generally choose social media with strong entertainment, such as Weibo and QQ group. The author thinks that these platforms cannot truly show the advantages of blended teaching mode and its driving force for higher education.

Moso Teach is a cloud service platform based on mobile intelligence device and auxiliary means to give feedback on teaching interaction in and outside class in time. Starting from students' learning habit, cognition habit, psychological habit and living habit, it is the effective combination of education law and information technology, and its long-term application can be helpful to teachers. Through Moso Teach, teachers can manage the whole class through phone or computer, timely interact with students and guide them to independently complete tasks given by teachers before, in and after class. The module design of Moso Teach is a beneficial platform for students' individualized learning, with rich teaching resources and activities, so that teachers and students can learn interactively, detailed record learning traces of students and provide corresponding process assessment record. Moso Teach integrates the advantage of blended learning with the application of network teaching platform and mobile social media, and avoids the drawbacks of the two. Moso Teach Web also can produce process assessment form according to the activities participated by students in the semester and their performance, to be full-participation, 
comprehensive and whole-procedural at the same time. [2] The blended teaching mode based on Moso Teach can flip the classroom, enliven the class, and mobilize teachers and students to obtain better teaching results. The blended teaching mode based on Moso Teach is not just a teaching reform, more a teaching method to deepen the cultivation of students' creative ability. Moso Teach, as the online resource platform of blended teaching reform and practice, based on Internet, builds new-type teaching space integrating “method reform, technology application and environment transformation”, satisfies students' online learning, cooperative learning, and timely interaction, supports project practice of groups and class, and constructs a coexistence of traditional entity classroom and blended classroom.

\section{The Feasibility and Purpose of Blended Teaching Based on Moso Teach}

In order to implement blended teaching based on Moso Teach in the whole university, several conditions shall be satisfied. First of all, relative departments of the university shall organize experts to conduct system training for teachers about how to perform Moso Teach teaching. On March 13, 2018, Jiang Bo, the Director of Xi'an Peihua University invited Jin Xin, the Chairman, to conduct a training on teaching in new era by the aid of Moso Teach, which has an impact on teaching concept of most teachers in traditional teaching. Some teachers began to make use of Moso Teach to conduct the teaching. On September, 2018, Xi'an Peihua University again invited Huang Weiming expert for a deepening training on Moso Teach, which meets the main conditions for the implementation of Moso Teach in Xi'an Peihua University. Secondly, the demonstration teaching reform area of blended teaching based on Moso Teach shall realize the comprehensive and stable coverage of WIFI. The condition for most students to participate in Moso Teach class is free WIFI and full coverage of WIFI. If teachers can use it but WIFI is not in full coverage, students would have problem on it, and even refuse to participate in tasks by teachers. Xi'an Peihua University currently has already realized that basically and incessantly improves and perfects it in practice. Thirdly, teachers shall reasonably arrange teaching design according to teaching content, including curriculum objective, clear overall program, rebuilding of teaching content according to students' situation, flipped content and task selection of Moso Teach, determination of program content, form purpose, supporting curriculum evaluation etc., but not all classroom content are completed on Moso Teach. Otherwise, it will increase the burden of teachers and students, students will dislike Moso Teach and refuse the blended teaching based on Moso Teach. Teachers shall make it clear that blended teaching mode is just one of methods to innovate education and teaching, and improve the quality of teaching, not the only one. The purpose of blended teaching mode based on Moso Teach is to be student-centered, and to serve applied curriculum reform, not arbitrarily. Besides, teachers are required to make it clear that there are also many drawbacks in blended teaching mode based on Moso Teach, which cannot solve all problems in teaching. Teachers in Xi'an Peihua University have higher quality and rich teaching experience, and can perform teaching design based on the flexible and appropriate application of Moso Teach according to the teaching. The teaching management is relatively strict and students are active. Therefore, there is certain feasibility for the implementation and application of blended teaching mode based on Moso Teach in Xi'an Peihua University.

Ideological and political education is the principal content in higher education and teaching. In traditional ideological and political course in our university, the overall class hour is not enough, there is less opportunities of practice for students, and teachers speed up the process with cramming education, which results in the low and identification and satisfaction from students for ideological and political course. The blended teaching mode based on Moso Teach, starting from the reality of the university and students, and the requirement of teaching management and teachers' quality improvement, being student-centered, serves the applied curriculum reform. Its effective implementation in Introduction to Mao Zedong Thought and the theoretical system of socialism with Chinese characteristics and Outline of Modern Chinese History can, firstly, change the drawbacks of traditional teaching to provide a giant resource database for students' ideological and political course; secondly, realize the sharing of teaching resources for teaching staff in teaching and research office to provide first-hand research data for teachers' 
science research; thirdly, strengthen the effective interaction between teachers and students of ideological and political course; fourthly, widen the influence of course, improve teaching results and quality and better realize the talent cultivation of the course; fifthly, firmly deepen the construction of innovation teaching and teaching reform of the course, promote the transformation of curriculum system to teaching system, aggregate high-quality teaching resources and promote the benign circulation of scientific research and teaching; sixthly, has certain popularization value and significance.

\section{The Implementation Method and Operation Process of Blended Teaching Based on Moso Teach}

In the exploration of this academic year, combined with the content of new version of teaching material of 2018, initial practice and breakthroughs made in this semester, through literature, test, observation, comparative research and experience conclusion research, based on Moso Teach, this paper makes three plans of before, in and after class of the course, and specific implementation process is shown in detail.

Firstly, before class (blended teaching of online and offline teaching). Teachers create a class number, and students join in the class. Before class, teachers shall make enough preparation of lessons, produce chapter PPT, search theme video related to chapters, download relative reading material, and load corresponding chapter PPT, pictures, videos, classic reading content or links according to different chapters through computer in Moso Teach resource database. After that, students can download and learn from Moso Teach, and teachers also can remind students who fail to download and watch to learn it. Besides, teachers also are required to load knowledge competition to test of Moso Teach through Moso Teach PC, set evaluation content, key points and evaluation objectives, to classroom activity. After teaching, teachers can evaluate the mastering of knowledge by students timely. By online teaching, students can obtain corresponding experience value by learning as a part of process evaluation. What's more, teachers give assignment or task from Moso Teach, under the guidance and arrangement of teachers, through independent learning and team cooperation, students shoot I Love- You Host, I am the Guide of Xi'an, history drama, micro film and video, Draw Chinese Story, Write Chinese Story, Translate Chinese Story and Propagate Chinese Story to teachers for evaluation, as a part of process evaluation. At the same time, teachers load excellent students' works to official account of “Artistic Ideological and Political Course" for learning, propagation and popularization, which mainly shows students' achievements and works in blended teaching reform with the orientation of activity.

Secondly, in class (blended teaching of online and offline teaching). First of all, ten minutes before the class, teachers play students' videos to guide them to know Xi'an history, learn news in China and outside China, and conduct in-depth thinking and discussion. If time is enough, teachers can guide students to give marks for different groups through classroom activity on Moso Teach. Second, teachers can give topic teaching and main line guidance for students. If necessary, they can present drama video of students according to teaching content and objective to expand the depth and width of students' learning, enhance their interest and recognition and realize teaching objective. Third, teachers are required to organize knowledge competition through Moso Teach classroom activity after the teaching. All tests of knowledge competition are made by student groups, searching from teaching materials and selecting tests of 10 single choice and 5 multiple choices to teachers for evaluation. After evaluation, teachers load those to Moso Teach knowledge competition to test the mastering of chapter content. At the same time, teachers are able to implement differentiation teaching for different class according to different mastering of knowledge content, with the help of students' answering of questions in class. To enliven classroom atmosphere, knowledge competition also can be conducted online and offline together. Finally, teachers and students come to the part of brainstorming. Teachers set up corresponding tests in Moso Teach classroom activity according to teaching content and students' major, and students answer questions within the allowed time. Teachers also can set students with excellent performance as assistant to help them to evaluate other students to mobilize their enthusiasm. 
Thirdly, after class (offline teaching). Students participate in the ideological and political course visual competition according to teacher's topic lecture content and online learning materials through independent learning and analysis and thinking, do innovation homework according to teacher's arrangement and their own major, under the arrangement and cooperation of teacher's organization and relevant departments, and present the concept, content, creation process and significance of creative works for marks and appraisal by professional judges. At last, with the help of related departments of news center, teachers can promote students' learning achievements of the course through Internet and official account platform to strengthen their sense of obtaining.

\section{The Application Effects of Teaching}

According to the content and procedure of curriculum design, based on Moso Teach, blended teaching of online and offline teaching before, in and after class is conducted on Introduction to Mao Zedong Thought and the theoretical system of socialism with Chinese characteristics and Outline of Modern Chinese History, and a new-type classroom and extracurricular teaching system of student-centered task experience is built, to enrich students' class and extracurricular practical activities, and realize the dynamic teaching mode with students' individualized learning, cooperative learning, online and offline learning, the interaction, answering and questioning and discussion between students and students, and students and teachers. The results of practice show that the blended teaching based on Moso Teach realizes the "integration of ideological and political course and major", and improves students' seven capabilities, including international horizon and communication, knowledge obtaining and internalization, speculative thinking ability, expression and communication, commitment and team working, knowledge application and innovation, and political quality, so that students become busy and active in the course and the course is enlivened. Its practice and application in the course realizes the task of curriculum teaching system and capabilities of task system, greatly improves the participation of students, from passive learning to active research and participation, inspires students' enthusiasm and innovative spirit, and enhances their sense of obtaining from ideological and political course.

Although the blended teaching based on Moso Teach is greatly advantageous over traditional teaching methods, some problems that need to be further improved in its teaching applications shall also be focused on. For instance, whether Moso Teach can increase the function of positioning and attendance, whether it can show the specific time of students' participation in activities, whether it can improve the student-oriented management system of teaching assistant, whether it can increase related functions to provide relative rights for teachers to timely observe the dynamics of students and strengthen the management and supervise; [3] whether it can be not constrained in the setting of objective multiple choices, increasing subjective questions in tests, so as to be convenient for teachers to conduct comprehensive evaluation on students. [4]

\section{Conclusion}

The development of everything has two sides, and there is no exception for blended teaching. The practical application of blended teaching based on Moso Teach in the ideological and political course, on the one hand, reflects the deep integration of Internet technology and traditional classroom teaching method in the context of information age. It conforms to the student-oriented teaching philosophy in applied technology colleges which greatly emphasizes students' emotional experience and individualized needs, improves the opposition condition between educators and educational objects, and realizes the democratization of education as well. It will make the teaching mode more vivid and diversified, and strengthen the timeliness at the same time. [5] On the other hand, there are also some problems in Moso Teach platform. It is not suitable for long-term teaching, and is not recommended for teachers to use it only in the purpose of usage. According to the discussion above, this study recommends teachers to choose blended teaching based on Moso Teach platform reasonably, and to combine different teaching 
content, objectives with the actual needs of students in the class when making the teaching design, hereby to effectively improve the teaching quality and serve the education in applied technology colleges.

\section{Acknowledgment}

Project program: This work is the phased research result of special key project of ideological and political education reform in 2018 of Xi'an Peihua University, "Research on Exploration and Practice of Blended Teaching Mode Reform in Ideological and Political Course Based on Moso Teach”.

\section{References}

[1]. Miao Qijun. Exploration of Blended Teaching in Accounting Course under the Background of Internet-Based on Moso Teach [J], Finance and Accounting Monthly, 2017 (33).

[2]. Wang Yanru. Application of Moso Teach in Higher Education [J], Education Modernization, 2017, 12, (49).

[3]. Bian Jing. Teaching Practice Exploration of Flipped Classroom for Ideological and Political Course Based on Moso Teach [J]. Journal of Changzhou Vocational College of Information Technology, 2017, 12, (4).

[4]. Zhang Yuchao. Reflection on the Reform and Practice of Teaching Based on Moso Teach [J]. Journal of Shijiazhuang Institute of Railway Technology, 2017, 12, (4).

[5]. Zhao Limei. Discussion on the Application of Moso Teach on "Two Courses" Teaching in Higher Vocational Colleges [J]. Journal of Liaoning Agricultural Technical College, 2017, 1, (1). 